\title{
Longer than life
}

Citation for published version (APA):

Brodersen, H. (2020). Longer than life: How the ICTY strengthened the rule of law in Bosnia and Herzegovina and Serbia. [Doctoral Thesis, Maastricht University]. Eleven International publishing. https://doi.org/10.26481/dis.20201008kb

Document status and date:

Published: 01/01/2020

DOI:

10.26481/dis.20201008kb

Document Version:

Publisher's PDF, also known as Version of record

\section{Please check the document version of this publication:}

- A submitted manuscript is the version of the article upon submission and before peer-review. There can be important differences between the submitted version and the official published version of record.

People interested in the research are advised to contact the author for the final version of the publication, or visit the DOI to the publisher's website.

- The final author version and the galley proof are versions of the publication after peer review.

- The final published version features the final layout of the paper including the volume, issue and page numbers.

Link to publication

\footnotetext{
General rights rights.

- You may freely distribute the URL identifying the publication in the public portal. please follow below link for the End User Agreement:

www.umlib.nl/taverne-license

Take down policy

If you believe that this document breaches copyright please contact us at:

repository@maastrichtuniversity.nl

providing details and we will investigate your claim.
}

Copyright and moral rights for the publications made accessible in the public portal are retained by the authors and/or other copyright owners and it is a condition of accessing publications that users recognise and abide by the legal requirements associated with these

- Users may download and print one copy of any publication from the public portal for the purpose of private study or research.

- You may not further distribute the material or use it for any profit-making activity or commercial gain

If the publication is distributed under the terms of Article $25 \mathrm{fa}$ of the Dutch Copyright Act, indicated by the "Taverne" license above, 


\section{Abstract}

The ICTY closed its doors in 2017. It had been set up in 1993 in order to prosecute crimes committed during the Yugoslav wars in the 1990s. Although its mandate was limited to that of a criminal court, the Tribunal aimed at strengthening the rule of law in the countries under its jurisdiction.

This book examines in what respect the ICTY had an impact on the Bosnian and Serbian criminal justice systems. It examines five areas where the footprint of the international tribunal is most tangible: national war crimes institutions, domestic criminal legislation and jurisprudence, witnesses' and victims' matters, and the use of technology in the criminal process. In the end, it is determined whether this influence indeed contributed to the rule of law in Bosnia and Herzegovina and Serbia.

Academics might be interested in this research as it contributes to understanding the domestic impact of international institutions. Practitioners will be guided in setting up and operating international war crimes courts, if strengthening the rule of law is a desired (side-)effect of that court. 